\title{
Mineral Composition of Four Edible Mushrooms
}

\author{
S. E. Mallikarjuna, ${ }^{1}$ A. Ranjini, ${ }^{2}$ Devendra J. Haware, ${ }^{2}$ M. R. Vijayalakshmi, ${ }^{1}$ \\ M. N. Shashirekha, ${ }^{1}$ and S. Rajarathnam ${ }^{1}$ \\ ${ }^{1}$ Department of Fruit and Vegetable Technology, Central Food Technological Research Institute, CSIR, Mysore 570020, India \\ ${ }^{2}$ Department of Food Safety and Analytical Quality Control Laboratory, Central Food Technological Research Institute, CSIR, \\ Mysore 570020, India
}

Correspondence should be addressed to S. Rajarathnam; rajarathnams@yahoo.com

Received 5 June 2012; Revised 20 July 2012; Accepted 7 August 2012

Academic Editor: Beatriz Oliveira

Copyright (C) 2013 S. E. Mallikarjuna et al. This is an open access article distributed under the Creative Commons Attribution License, which permits unrestricted use, distribution, and reproduction in any medium, provided the original work is properly cited.

\begin{abstract}
Two cultivated mushroom species, namely, Lentinula edodes and Pleurotus florida and two wild growing species Lentinus cladopus and Pleurotus djamor were studied for their mineral contents such as $\mathrm{Ca}, \mathrm{Mg}, \mathrm{Na}, \mathrm{K}, \mathrm{Fe}, \mathrm{Zn}, \mathrm{Mn}, \mathrm{Cu}, \mathrm{Ni}$, Se, $\mathrm{Pb}$, and $\mathrm{Cd}$ by Inductive Coupled Plasma Atomic Emission Spectroscopy (ICP-AES) and also Atomic Absorption Spectroscopy, (AAS). Phosphorus was estimated by spectrophotometric method. $\mathrm{K}, \mathrm{Ca}, \mathrm{Na}$, and $\mathrm{P}$ were in higher concentrations ranging from $59.3 \mathrm{mg}$ to $3634 \mathrm{mg}$, $8.27 \mathrm{mg}-174.9 \mathrm{mg}, 22.2 \mathrm{mg}-327.4 \mathrm{mg}$, and $100.5 \mathrm{mg}-769.9 \mathrm{mg} / 100 \mathrm{~g}$ dry weight respectively in the four mushroom species studied. $\mathrm{Fe}, \mathrm{Zn}, \mathrm{Mg}$ and Se were ranging from $6.27 \mathrm{mg}$ to $35.3 \mathrm{mg}, 1.58 \mathrm{mg}-9.44 \mathrm{mg}, 21.1 \mathrm{mg}-40.7 \mathrm{mg}$ and $0.048 \mathrm{mg}-0.182 \mathrm{mg} / 100 \mathrm{~g}$ dry weight, respectively, amongst the mushroom species analyzed. However, $\mathrm{Ni}, \mathrm{Cu}$, and $\mathrm{Mn}$ contents showed relatively lower concentrations, whereas $\mathrm{Pb}$ and $\mathrm{Cd}$ were below detectable level. The mushrooms were safe for consumption, in accordance with the permissible tolerance limits of the estimated toxic metals. Implications of the mineral contents on mushroom nutritional value are highlighted.
\end{abstract}

\section{Introduction}

Mushrooms are important in the ecosystem because they are able to biodegrade the substrate and therefore use the wastes of agricultural production. Fruiting bodies of mushrooms are appreciated, not only for texture and flavor [1-6] but also for their chemical [7-9] and nutritional properties [10-16]. Mushrooms have also been reported as therapeutic foods, useful in preventing diseases such as hypertension, hypercholesterolemia, and cancer. These functional characteristics are mainly due to their chemical composition [11, 17].

Organisms require trace amounts of some heavy metals, including iron, cobalt, copper, manganese, chromium, and zinc. Excessive levels of these metals, however, can be detrimental to organisms. Other heavy metals such as cadmium and lead have no known beneficial effect on organisms [1]. The ability of mushroom species to bioaccumulate the minerals from the growth medium into the fruiting body is well documented $[18,19]$. Because of ecological and genetic but known factors, the fruiting bodies of higher mushrooms often are relatively rich in mineral constituents [2022]. Environmental factors such as species of mushrooms, morphological part of fruiting body, developmental stages and age of mycelium, biochemical composition, and interval between the fructifications affect mineral accumulation in macro fungi $[23,24]$. Iron, copper, manganese, zinc (trace elements), lead, cadmium, and nickel (toxic metals) were chosen as representatives, whose levels in the environment represent a reliable index of environmental pollution [24]. Minerals such as iron, copper, zinc and manganese are essential metals since they play an important role in biological systems, whereas lead and cadmium are nonessential metals as they are toxic, even in traces [25]. The essential metals can also produce toxic effects when the metals intake is excessively elevated [24].

In this context, it is worthwhile to evaluate (a) the metal content in mushrooms grown on any substrate, (artificially/natural occurrence), (b) to assess the contribution of 
mushrooms to the daily intake of several toxic elements, and (c) to compare the results with the norms for these toxic elements in food stuff, so that it would help to adjudicate the mushrooms for their nutritional value in terms of minerals and also to define the limits of safety $[24,26]$.

Thus, the present paper is focused on the analysis of four species of mushrooms namely Lentinus cladopus, Lentinula edodes, Pleurotus djamor, and Pleurotus florida for their mineral contents and to discuss the results generated on essential and trace elements in edible mushrooms, along with the limits of toxic metals. In the perspective that mushrooms do significantly contribute to the minerals in the human diet, the data derived would serve as an useful basis to define the nutritional value of a given mushroom species, along with any warnings for toxic minerals, depending on the concentration(s).

\section{Experimental}

2.1. Mushroom Samples. Fruiting bodies ( $3 \mathrm{~kg}$ fresh or equivalent) of Lentinus cladopus Leveille and Pleurotus djamor Sacc were collected from forest areas of Shimla in Himachal Pradesh, while the fruiting bodies of Lentinula edodes (Berk.) Pegler grown on saw dust composite substrate in laboratory was received from Maharana Prathap University of Agriculture and Technology (MPUAT), Udaipur. Pleurotus florida (Block \& Tsao) was cultivated on rice straw in laboratory at Central Food Technological Research Institute, (CFTRI) Mysore. The fruiting bodies ( $3 \mathrm{~kg}$ fresh or equivalent) were cleaned, sliced, and dried in hot air drier at $55^{\circ} \mathrm{C}$ to a residual moisture of $\sim 5 \%$ and then the dried mushroom samples were powdered to $\sim 1 \mathrm{~mm}$ particle size and stored at room temperature in precleaned polyethylene bottles until analysis.

2.2. Preparation of Ash Solution. One gram of dry powdered sample was placed in a porcelain crucible and ashed at $450^{\circ} \mathrm{C}$ for 5-6 h; then the ash was dissolved in $2 \mathrm{~mL}$ concentrated $\mathrm{HNO}_{3}$ (Merck), and heated on a low heat for $1 \mathrm{~min}$. Then, it was cooled and filtered through Whatman No. 42 filter paper to a $50 \mathrm{~mL}$ volumetric flask and was made to volume with triple distilled water. A blank was also prepared using similar experimental procedure [33]. Three such replicates were maintained for each of the mushroom species studied.

2.3. Instrumentation. The mineral contents were determined employing Atomic Absorption Spectrometer (AAS), [Analyst 700 Perkin Elmer, USA] with air-acetylene burner for flame and Inductively Coupled Plasma Atomic Emission Spectrometer (ICP-AES) [ACTIVIA-M, Horiba Jobin yvon] with Argon plasma.

2.4. Mineral Analysis. Aliquot of the ash solution was aspirated to the instrument (AAS/ICP-AES) for the determination of metals/minerals namely., Ca, Mg, Na, K, Fe, Zn, Mn, $\mathrm{Cu}, \mathrm{Ni}, \mathrm{Se}, \mathrm{Pb}$, and $\mathrm{Cd}$.

Calibration of AAS was done using the working standard prepared from commercially available metal/mineral standard solutions ( $1000 \mu \mathrm{g} / \mathrm{mL}$, Merck, Germany). The most appropriate wavelength, hallow cathode lamp current, gas mixture flow rate, slit width, and other AAS instrument parameters for metals/minerals were selected as given in the instrument user's manual, and background correction was used during determination of metals/minerals. Measurements were made within the linear range of working standards used for calibration [33].

Working conditions of AAS were as follows:

instrument: AAS (Perkin Elmer A Analyst 700),

flame temperature: $2800^{\circ} \mathrm{C}$,

acetylene pressure: $0.9-1.0 \mathrm{bar}$,

air pressure: $4.5-5$ bar,

reading time: $1-10 \mathrm{sec}(\max 60 \mathrm{sec})$,

flow time: 3-4 sec ( $\max 10 \mathrm{sec})$.

Calibration of ICP-AES was done using the working standard prepared from commercially available multielement standard solution (100 mg/L, Merck, Germany). The most appropriate wave length, Argon gas flow, Plasma stabilization, and other ICP-AES instrument parameters for metals/minerals were selected, and measurements were made within linear range of working standards used for calibration [33].

Working conditions of ICP-AES were as follows:

instrument: ICP-AES (ACTIVIA-M, Horiba Jobinyvon),

power: $1000 \mathrm{~W}-1200 \mathrm{~W}$,

plasma gas flow: $12-16 \mathrm{~L} / \mathrm{min}$,

auxillary gas flow: $0.8 \mathrm{~L} / \mathrm{min}$,

plasma burning height: $5-22 \mathrm{~mm}$,

reading time: $1-10 \mathrm{sec}(\max 60 \mathrm{~s})$,

flow time: $2-3 \mathrm{sec}(\max 10 \mathrm{~s})$.

Phosphorus was determined by spectrophotometric method, wherein phosphorus reacts with molybdic acid to form phosphomolybdate complex, which was then reduced with amino naphthol sulfonic acid to complex molybdenum blue that was measured spectrophotometrically [35].

The concentrations of all the minerals were expressed as $\mathrm{mg} / 100 \mathrm{~g}$ dry weight of the sample. The limit of detection for $\mathrm{Pb}$ was $0.05 \mathrm{mg} / 100 \mathrm{~g}$ and for $\mathrm{Cd}$ was $0.01 \mathrm{mg} / 100 \mathrm{~g}$ on dry weight basis. Each value is the mean of three replicate determination \pm standard deviation.

\section{Results and Discussion}

Minerals represent the ash left behind after complete incineration of the dry mushroom. The mineral composition reflects on the growth conditions of the mushroom. Minerals such as potassium, calcium are said to be major because they are in high concentrations of the mushroom, as well as phosphorus and magnesium. However, sodium is relatively less in mushroom species; thus, mushrooms are said to be good for patients with hypertension [18]. Similar observations were made in the present study too. 
TABLE 1: Major element concentrations (mg/100 g on dry weight basis) in four species of mushrooms.

\begin{tabular}{lcccc}
\hline Elements & Lentinula edodes & Lentinus cladopus & Pleurotus florida & Pleurotus djamor \\
\hline Potassium & $1302 \pm 101$ & $59.3 \pm 10.2$ & $2472 \pm 207$ & $3634 \pm 122$ \\
Phosphorus & $769.9 \pm 64.1$ & $100.5 \pm 2.3$ & $640.2 \pm 8.0$ & $743.2 \pm 29.8$ \\
Calcium & $174.9 \pm 34.3$ & $129.9 \pm 26.1$ & $8.27 \pm 0.2$ & $34.2 \pm 29.9$ \\
Sodium & $327.4 \pm 51.6$ & $22.2 \pm 0.6$ & $30.5 \pm 8.0$ & $61.6 \pm 8.2$ \\
Magnesium & $40.7 \pm 1.2$ & $21.1 \pm 3.5$ & $35.9 \pm 1.9$ & $31.6 \pm 1.7$ \\
\hline
\end{tabular}

Each value is the mean of three replicate determinations \pm standard deviation.

TABLE 2: Trace element concentrations ( $\mathrm{mg} / 100 \mathrm{~g}$ on dry weight basis) in four species of mushrooms.

\begin{tabular}{lcccc}
\hline Elements & Lentinula edodes & Lentinus cladopus & Pleurotus florida & Pleurotus djamor \\
\hline Iron & $14.8 \pm 2.3$ & $35.3 \pm 3.55$ & $6.27 \pm 0.41$ & $14.8 \pm 0.91$ \\
Zinc & $9.44 \pm 0.24$ & $1.58 \pm 0.21$ & $5.06 \pm 0.04$ & $9.21 \pm 0.03$ \\
Copper & $1.48 \pm 0.03$ & $0.97 \pm 0.01$ & $1.06 \pm 0.06$ & $1.45 \pm 0.08$ \\
Manganese & $1.00 \pm 0.32$ & $0.54 \pm 0.01$ & $0.62 \pm 0.03$ & $1.12 \pm 0.03$ \\
Selenium & $0.182 \pm 0.01$ & $0.19 \pm 0.01$ & $0.048 \pm 0.02$ & $0.11 \pm 0.04$ \\
\hline
\end{tabular}

Each value is the mean of three replicate determinations \pm standard deviation.

To overcome the inaccuracies borne in differences in moisture contents from different authors from different parts of the world, on fresh weight basis, and to ensure universal comparison of data, all the values obtained were expressed here on moisture free basis. Amongst the four mushroom species studied (Lentinus cladopus, and Pleurotus djamor growing wild, and Lentinula edodes, Pleurotus florida cultivated), potassium ranged from 59.3 to $3634 \mathrm{mg} / 100 \mathrm{~g}$ dry weight (Table 1). Phosphorous also recorded relatively higher contents, followed by calcium. However, levels of sodium were less except Lentinula edodes. Magnesium ranged from 23.1 to $40.7 \mathrm{mg} / 100 \mathrm{~g}$ dry weight and thus emphasizing mushroom as a good source of magnesium.

Iron, zinc, copper, manganese, and selenium are dealt with under minor/trace elements. L. cladopus showed high value for iron $(35.3 \mathrm{mg} / 100 \mathrm{gdry} w \mathrm{t})$. Zinc was higher in L. edodes and mushrooms are said to be good biological accumulators of zinc, and zinc is biologically very vital to the human body [36]. Copper and manganese were in a relatively low concentration in all the four species analyzed (Table 2). Selenium was in fairly good concentrations, and selenium is known for fighting against cancer [37]. This is organic selenium as found in the mushroom fruiting body, and mushrooms are known for bioconversion of such minerals from the growth substrate from inorganic form to organic form [38]. Concentration of nickel in the studied mushroom species is very low. Lead and cadmium were below detection levels (Table 3). The occurrence and distribution of different toxic components in certain mushrooms is not only a theoretical mycological problem but also has practical environmental and toxicological aspects [39]. According to $\mathrm{FAO} / \mathrm{WHO}[19]$ tolerable weekly intake of cadmium and lead are 0.007 and $0.025 \mathrm{mg} / \mathrm{kg}$ body weight, respectively. The lead and cadmium levels in all studied species are very low and thus, these mushroom species are safe for consumption.

Thus, the minerals analyzed in the four mushroom species were quite comparable with reported literature values
(Table 4). Based on the minerals of these mushroom species converted on a scale for $100 \mathrm{~g}$ fresh (based on the $90 \%$ moisture content), eventually signifies the minerals available in $100 \mathrm{~g}$ fresh mushrooms that can be consumed per day. The situation becomes quite practical when considered consumption of $100 \mathrm{~g}$ fresh at least five times a week. Recommended minerals intake for trace and permissible limits of the toxic metals along with references are presented in Table 5.

\section{Conclusions}

The four mushroom species analyzed for their mineral contents conform as sources of calcium, potassium, iron, and zinc and less in sodium.

Accordingly, these species are good supplementary health foods from the angle of human nutrition. More importantly, it is vital to always relate the mushroom mineral contents with specificities of growth substrates on which the species under study is grown, further based on their nonstarchy carbohydrates [5], sugar alcohols [18], and vitamin contents [7]. The present mineral values add to the safe consumption of mushrooms as supplementary foods to the populations preponderantly dependent on cereal diet.

\section{Abbreviations}

AAS: $\quad$ Atomic Absorption Spectra

ICP-AES: Inductively Coupled Plasma Atomic

Emission Spectrometer.

\section{Acknowledgments}

The authors are grateful to the Director of CFTRI, Mysore. This study was funded by Department of Biotechnology, Government of India, New Delhi. 
TABLE 3: Toxic metal concentrations (mg/100 g on dry weight basis) in four species of mushrooms.

\begin{tabular}{lcccc}
\hline Metals & Lentinula edodes & Lentinus cladopus & Pleurotus florida & Pleurotus djamor \\
\hline Nickel & $0.15 \pm 0.03$ & $0.09 \pm 0.03$ & $0.07 \pm 0.04$ & $0.15 \pm 0.04$ \\
Lead & $\mathrm{BDL}^{\mathrm{a}}$ & $\mathrm{BDL}^{\mathrm{a}}$ & $0.092 \pm 0.002$ & $0.12 \pm 0.07$ \\
Cadmium & $\mathrm{BDL}^{\mathrm{a}}$ & $\mathrm{BDL}^{\mathrm{a}}$ & $\mathrm{BDL}^{\mathrm{a}}$ & $\mathrm{BDL}^{\mathrm{a}}$ \\
\hline
\end{tabular}

Each value is the mean of three replicate determinations \pm standard deviation.

${ }^{a}$ BDL: Below detectable level.

TABLE 4: Range of reported literature values (mg/100 g dry weight basis) in mushroom.

\begin{tabular}{lcc}
\hline Mineral elements & $\begin{array}{c}\text { Range of literature value } \\
(\mathrm{mg} / 100 \text { g dry wt })\end{array}$ & Reference \\
\hline Potassium & $2500-4100$ & {$[27]$} \\
Phosphorus & $120.0-2000$ & {$[28]$} \\
Calcium & $1.8-59.0$ & {$[28]$} \\
Sodium & $6.0-92$ & {$[28]$} \\
Magnesium & $60-250$ & {$[27]$} \\
Iron & $1.46-83.5$ & {$[29]$} \\
Zinc & $2.98-15.8$ & {$[30]$} \\
Copper & $7.1-9.5$ & {$[29]$} \\
Manganese & $1.81-10.3$ & {$[31]$} \\
Selenium & $1-5$ & {$[32]$} \\
Nickel & $0.118-0.514$ & {$[29]$} \\
Lead & $0.286-0.688$ & {$[30]$} \\
Cadmium & $0.271-0.75$ & {$[30]$} \\
\hline
\end{tabular}

TABLE 5: Recommended Daily Intake (RDI) of trace elements.

\begin{tabular}{lcc}
\hline Element & RDI & Reference \\
\hline $\mathrm{Cu}$ & $2.2 \mathrm{mg} /$ day & {$[34]$} \\
$\mathrm{Fe}$ & $28-30 \mathrm{mg} /$ day & {$[34]$} \\
$\mathrm{Zn}$ & $15.5 \mathrm{mg} /$ day & {$[34]$} \\
$\mathrm{Mn}$ & $5.5 \mathrm{mg} /$ day & {$[34]$} \\
\hline
\end{tabular}

\section{References}

[1] P. K. Ouzouni, D. Petridis, W. D. Koller, and K. A. Riganakos, "Nutritional value and metal content of wild edible mushrooms collected from West Macedonia and Epirus, Greece," Food Chemistry, vol. 115, no. 4, pp. 1575-1580, 2009.

[2] Z. Bano, S. Rajarathnam, and M. N. Shashirekha, "Mushrooms-the unconventional single cell protein for a conventional consumption," Indian Food Packer, vol. 46, no. 6, pp. 20-31, 1992.

[3] Z. Bano, S. Rajarathnam, and M. N. Shashirekha, "Production and processing of mushrooms," Food Digest, vol. 16, no. 1, pp. 61-69, 1993.

[4] S. Rajarathnam and Z. Bano, "Biological utilization of the fruiting fungi," in Advances in Applied Mycology, vol. 3, pp. 241-392, Marcel Dekker Press, New York, NY, USA, 1990.

[5] S. Rajarathnam, M. N. Shashirekha, and Z. Bano, "Biopotentialities of the basidiomacromycetes," in Advances in Applied Mycology, vol. 37, pp. 234-361, Academic Press, San Diego, Calif, USA, 1992.
[6] Y. L. Lee, S. Y. Jian, and J. L. Mau, "Composition and nonvolatile taste components of Hypsizigus marmoreus," Lebensmittel-Wissenschaft \& Technologie, vol. 42, no. 2, pp. 594-598, 2009.

[7] Z. Bano and S. Rajarathnam, "Vitamin values of Pleurotus mushrooms," Qualitas Plantarum Plant Foods for Human Nutrition, vol. 36, no. 1, pp. 11-15, 1986.

[8] Z. Bano and S. Rajarathnam, "Pleurotus mushrooms. Part II. Chemical composition, nutritional value, post-harvest physiology, preservation, and role as human food," Critical Reviews in Food Science and Nutrition, vol. 27, no. 2, pp. 87-158, 1988.

[9] S. Kavishree, J. Hemavathy, B. R. Lokesh, M. N. Shashirekha, and S. Rajarathnam, "Fat and fatty acids of Indian edible mushrooms," Food Chemistry, vol. 106, no. 2, pp. 597-602, 2008.

[10] Z. Bano and S. Rajarathnam, "Pleurotus mushrooms as a nutritious food," in Tropical Mushrooms, Biological Nature and Cultivation Methods, S. T. Chang and T. H. Quimio, Eds., pp. 363-382, Chinese University Press, Hong Kong, China, 1982.

[11] G. P. Netravathi, U. V. Sathisha, M. D. Shylaja, M. N. Shashirekha, and S. Rajarathnam, "Antioxidant activity of indigenous edible mushrooms," Journal of Agricultural and Food Chemistry, vol. 54, no. 26, pp. 9764-9772, 2006.

[12] S. Rajarathnam, Z. Bano, and M. V. Patwardhan, "Post-harvest physiology and storage of the white oyster mushroom, Pleurotus flabellatus," Journal of Food Technology, vol. 18, pp. 153-162, 1983.

[13] M. N. Shashirekha, S. Rajarathnam, and Z. Bano, "Effects of supplementing rice straw growth substrate with cotton seeds on the analytical characteristics of the mushroom, Pleurotus florida (Block \& Tsao)," Food Chemistry, vol. 92, no. 2, pp. 255-259, 2005.

[14] L. Barros, P. Baptista, D. M. Correia, S. Casal, B. Oliveira, and I. C. F. R. Ferreira, "Fatty acid and sugar compositions, and nutritional value of five wild edible mushrooms from Northeast Portugal," Food Chemistry, vol. 105, no. 1, pp. 140-145, 2007.

[15] S. Rajarathnam and M. N. Shashirekha, "Mushrooms and truffles: use of wild mushrooms," in Encyclopedia of Food Science and Nutrition, pp. 4048-4054, Academic Press, London, UK, 2003.

[16] S. Beluhan and A. Ranogajec, "Chemical composition and nonvolatile components of Croatian wild edible mushrooms," Food Chemistry, vol. 124, no. 3, pp. 1076-1082, 2011.

[17] M. N. Shashirekha and S. Rajarathnam, "Mushroom nutraceuticals," in Advances in preservation and processing technologies of fruits and vegetables, S. Rajarathnam and R. S. Ramteke, Eds., pp. 605-656, New India Publishing Agency, New Delhi, India, 2011.

[18] S. Rajarathnam, M. N. Shashirekha, and Z. Bano, "Biodegradative and biosynthetic capacities of mushrooms: present and future strategies," Critical Reviews in Biotechnology, vol. 18, no. 2-3, pp. 91-236, 1998. 
[19] P. Kalač, "Trace element contents in European species of wild growing edible mushrooms: a review for the period 2000-2009," Food Chemistry, vol. 122, no. 1, pp. 2-15, 2010.

[20] J. A. Schmitt, H. U. Meisch, and W. Reinle, "Heavy metals in higher fungi, II, manganese and iron," Zeitschrift fur Naturforschung C, vol. 32, no. 9-10, pp. 712-723, 1977 (German).

[21] P. Varo, O. Lahelma, M. Nuurtamo, E. Saari, and P. Koivistoinen, "Mineral element composition of finish foods, vii. potato, vegetables, fruits, berries, nuts and mushrooms," Acta Veterinaria Scandinavica, vol. 22, pp. 89-113, 1980.

[22] J. Vetter, "Mineral element content of edible and poisonous macrofungi," Acta ali zagon civilne družbe, vol. 19, pp. 27-40, 1990.

[23] M. A. García, J. Alonso, M. I. Fernández, and M. J. Melgar, "Lead content in edible wild mushrooms in Northwest Spain as indicator of environmental contamination," Archives of Environmental Contamination and Toxicology, vol. 34, no. 4, pp. 330-335, 1998.

[24] S. Mustafa, S. Sibal, T. Mustafa, and M. Durali, "Determination of trace metals in mushroom samples from Kayseri, Turkey," Food Chemistry, vol. 92, no. 4, pp. 649-652, 2005.

[25] H. A. Schroeder, The Trace Elements and Nutrition, Faber and Faber, London, UK, 1973.

[26] C. Sarikurkcu, M. Copur, D. Yildiz, and I. Akata, "Metal concentration of wild edible mushrooms in Soguksu National Park in Turkey," Food Chemistry, vol. 128, no. 3, pp. 731-734, 2011.

[27] L. R. Bakken and R. A. Olsen, "Accumulation of radiocaesium in fungi," Canadian Journal of Microbiology, vol. 36, no. 10, pp. 704-710, 1990

[28] J. Falandysz, K. Szymczyk, H. Ichihashi et al., "ICP/MS and ICP/AES elemental analysis (38 elements) of edible wild mushrooms growing in Poland," Food Additives and Contaminants, vol. 18 , no. 6 , pp. 503-513, 2001.

[29] M. Tüzen, "Determination of heavy metals in soil, mushroom and plant samples by atomic absorption spectrometry," Microchemical Journal, vol. 74, no. 3, pp. 289-297, 2003.

[30] M. Işlolu, F. Ylmaz, and M. Merdivan, "Concentrations of trace elements in wild edible mushrooms," Food Chemistry, vol. 73, no. 2, pp. 169-175, 2001.

[31] M. Durali, D. U. Ozgur, T. Musatafa, H. Erdogan, and S. Hayati, "Trace metal levels in mushroom samples from Ordu, Turkey," Food Chemistry, vol. 91, no. 3, pp. 463-467, 2005.

[32] P. Kalač and L. Svoboda, "A review of trace element concentrations in edible mushrooms," Food Chemistry, vol. 69, no. 3, pp. 273-281, 2000.

[33] Association of Official Analytical Chemists, Official Methods of Analysis, Association of Official Analytical Chemists, Washington, DC, USA, 18th edition, 2000.

[34] Indian Council of Medical Research, Nutrient Requirements and Recommended Dietary Allowances for Indians, A Report of the Expert Group of the Indian Council of Medical Research, National Institute of Nutrition, Hyderabad, 1990.

[35] Association of Official Analytical Chemists, Official Methods of Analysis, Association of Official Analytical Chemists, Washington, DC, USA, 12th edition, 1975.

[36] Z. Bano, K. Nagaraja, S. Vibhakar, and O. P. Kapur, "Minerals and heavy metal contents in the sporophores of Pleurotus species," Mushroom Newslett Tropics, vol. 2, pp. 3-7, 1981.

[37] B. Lipinski, "Rationale for the treatment of cancer with sodium selenite," Medical Hypotheses, vol. 64, no. 4, pp. 806-810, 2005.
[38] J. Falandysz, "Selenium in edible mushrooms," Journal of Environmental Science and Health C, vol. 26, no. 3, pp. 256-299, 2008.

[39] J. Vetter, "Data on arsenic and cadmium contents of some common mushrooms," Toxicon, vol. 32, no. 1, pp. 11-15, 1994. 

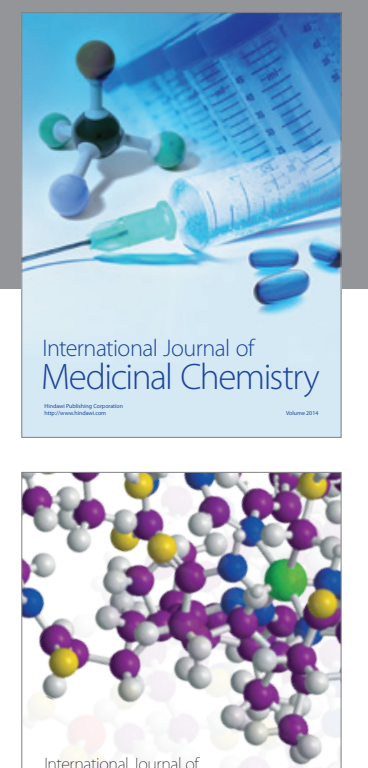

\section{Carbohydrate} Chemistry

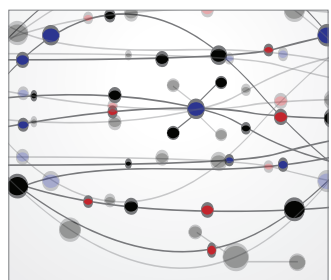

The Scientific World Journal
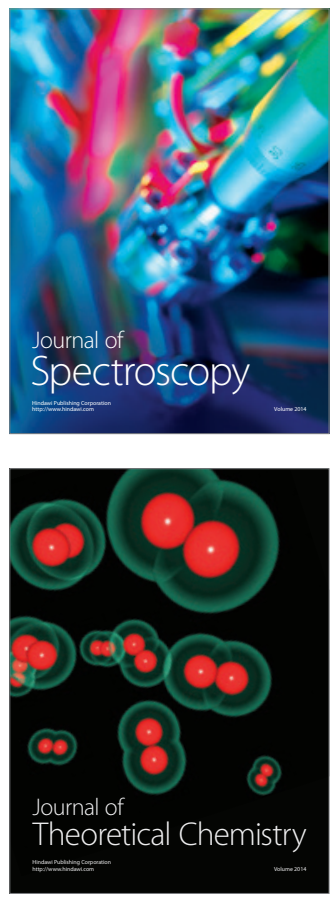
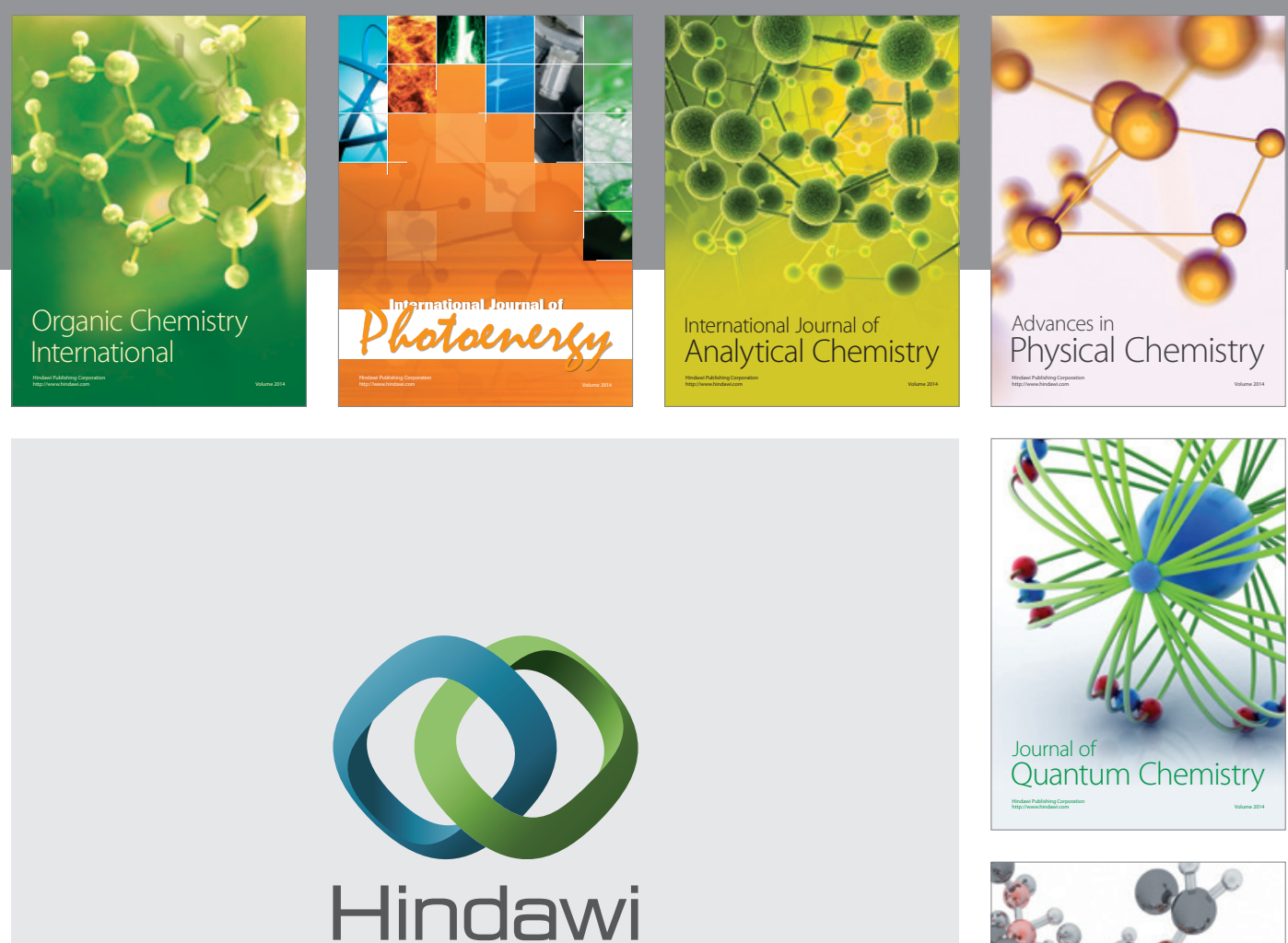

Submit your manuscripts at

http://www.hindawi.com

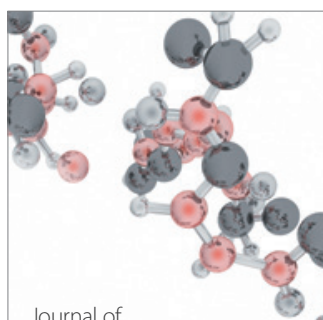

Analytical Methods

in Chemistry

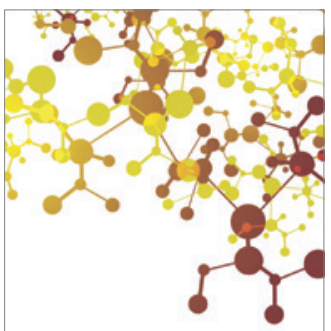

Journal of

Applied Chemistry

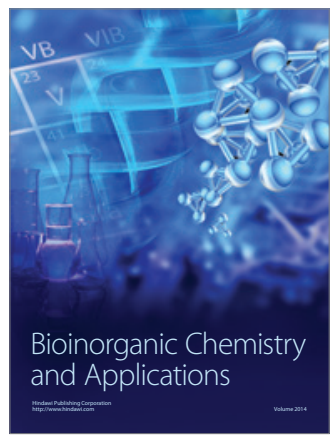

Inorganic Chemistry
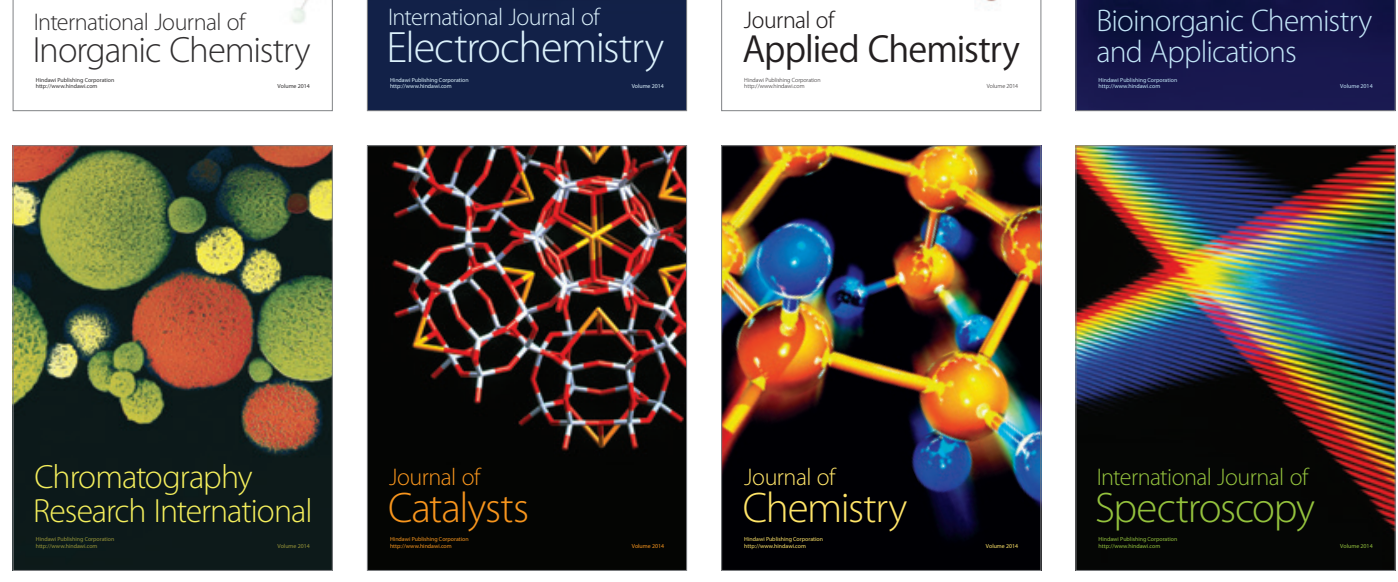